\title{
Antimicrobial Resistance in Salmonella spp. isolated from cattle gallbladder slaughtered in the south of the state of Rio de Janeiro
}

\section{Resistência a antimicrobianos em Salmonella spp. Isolada de vesículas biliares de bovinos abatidos no sul do estado do Rio de Janeiro}

\author{
Francesca Silva Dias, ${ }^{*}$ lacir Francisco dos Santos, ${ }^{*}$ Robson Maia Franco, ${ }^{* \star}$ Elmiro Rosendo Nascimento**
}

\begin{abstract}
Salmonella infections are an important cause of mortality and morbidity in cattle, and subclinically infected animals are frequently found. The microorganism may exhibit multiple antibiotic resistance and may be able to survive in harsh environments such as the gallbladder. Salmonella Multiple Antibiotic Resistance (MAR) was detected in bile and gallbladder epithelium from cattle slaughtered in a plant in southern state of Rio de Janeiro, Brazil, under sanitary conditions. The frequency of resistance to each drug was not significantly different between bile and epithelium, except in the case of cefotaxime, which showed increased resistance in the bile. Aztreonam was the most effective antibiotic for inhibiting strain growth. Since the results showed Salmonella spp. strains resistant to twelve antimicrobials, it denotes an alarming risk, therefore in cases of invasive infections in both human and animals there will be reduction of therapeutic options against the pathogen.
\end{abstract}

Keywords: Salmonella spp., gallbladder, cattle, antimicrobials, antibiotic resistance.

\section{Resumo}

Infecções causadas por Salmonella spp. são uma importante causa de mortalidade e morbidade em bovinos, e animais subclinicamente infectados são frequentemente encontrados. Salmonella spp. pode expressar múltipla resistência a antibióticos e ser capaz de sobreviver em ambientes inóspitos, como a vesícula biliar. Salmonella spp. com múltipla resistência a antibióticos foi detectada na bile e epitélio de vesículas biliares de bovinos abatidos em matadouro-frigorífico no sul do estado do Rio de Janeiro, Brasil, sob Inspeção Sanitária. A frequência de resistência a cada droga não foi significativamente diferente entre bile e epitélio, exceto no caso de cefotaxima, que mostrou grande resistência na bile. Aztreonam foi o antimicrobiano mais eficaz para inibir o crescimento da estirpe. Como na pesquisa foram identificadas salmonelas resistentes a 12 antimicrobianos testados, este patógeno torna-se alarmante, pois em casos de infecção invasiva em animais e humanos haverá redução de opção terapêutica.

Palavras-chave: Salmonella spp., vesicular biliar, bovino, antimicrobianos, resistência a antibióticos.

\section{Introduction}

Salmonella infections are an important cause of mortality and morbidity in cattle, and subclinically infected animals are frequently found. Cattle may constitute an important reservoir for human infections (Wray \& Davies, 2000). This genus exhibits resistance to many antibiotics and could become a problem in both human and veterinary medicine (Zhao et al., 2007). In cattle populations where antimicrobials are used, Salmonella species are under high selection pressure, and generic strains begin to present Multiple Antibiotic Resistance (MAR) (Defrancesco et al., 2004). According to data from SINDAN (2009), antibiotics are used extensively in livestock in Brazil; the amount spent on bovine species in 2009 was the equivalent of approximately one billion US dollars.
To survive in their host organism and spread throughout the food chain, Salmonella develop mechanisms that enable them to form permanent colonies and biofilms in harsh environments, triggering the establishment of chronic, asymptomatic carriers (Prieto et al., 2004; Dutta et al., 2000; Prouty et al., 2002; Steenackers et al., 2011). The gallbladder presents an example of adaptation by the microorganism in that Salmonella are highly resistant to bile (Gunn, 2000; Prouty et al., 2002; Van Velkinburgh and Gunn, 1999). To withstand the adverse conditions found in the gallbladder, including variable $\mathrm{pH}$, low oxygen and nutrient limitation (Begley et al., 2005), and still be resistant to many antimicrobial agents, extensive gene regulation is required. Bile induces drug resistance in the organism and the expression of genes required for pathogenesis (Prouty et al., 2004a; Prouty et al., 2004b).

\footnotetext{
${ }^{*}$ Postgraduate Program in Veterinary Medicine (MS) - Veterinary Hygiene and Processing Technology of Animal Products, Faculty of Veterinary Medicine, University Federal Fluminense - UFF. E-mai correspondence: francesca_dias@yahoo.com.br.

** Professor of the Department of Food Technology - UFF.
} 
Outbreaks of salmonellosis are common all over the country and often come from animal products. In addition, the observation that the gallbladder supports a high number of Salmonella strains suggests the possibility that cattle might be a persistent carrier of pathogens emerging as a risk to public health. The objective of the present study was to detect the presence of Salmonella strains in bile and gallbladder epithelium from cattle slaughtered in a plant under sanitary conditions and to evaluate the frequency of antimicrobial resistance in these strains.

\section{Material and methods}

\section{Samples}

Intact gallbladders were collected from 30 randomly selected healthy cattle, judged after ante-mortem and post-mortem inspection, in a slaughtering plant under sanitary conditions in the southern state of Rio de Janeiro, Brazil. Immediately after collection, the material was transported to the laboratory under refrigeration. Microbiological analysis was performed on the same day.

\section{Microbial Analysis and Phenotypic Identification}

The gallbladder was opened in aseptic conditions, bile was collected and the biliary epithelium was sectioned with the aid of sterilized instruments. Bile and gallbladder epithelium were analyzed separately for Salmonella spp., as described by Pignato et al. (1995). Twenty-five grams of bladder epithelium and $25 \mathrm{ml}$ of liquid bile were added to $225 \mathrm{ml}$ of preenrichment Salmosyst Base broth (Merck) in a sterile bag. The sterile bags were homogenized in a stomacher for 3 minutes and incubated for 6 hours at $37^{\circ} \mathrm{C}$. For the selective Salmosyst enrichment, $10 \mathrm{ml}$ of preenrichment broth base was supplemented with one selective supplement tablet (Merck) and incubated for 18 hours at $37^{\circ} \mathrm{C}$. Colony isolation was carried out in Rambach Agar (Merck), and typical colonies, after confirmation by Gram morphology, were subjected to biochemical identification using tests to verify the presence of cytochrome oxidase (Newprov ${ }^{\circledR}$, Brazil), production of urease in urea broth (Himedia), fermentation of glucose, sucrose and lactose in Triple Sugar Iron (TSI) medium (Himedia), lysine decarboxylation in Lysine Iron Agar (LIA) medium (Himedia); production of $\mathrm{H}_{2} \mathrm{~S}$ in Sulfide Indole Motility (SIM) medium (Himedia) and VogesProskauer reaction in Methyl Red-Voges Proskauer (VM-VP) broth (BioChemika - Sigma-Aldrich). In addition, serological tests were performed using somatic polyvalent Salmonella "Vi" and "H" antisera (Probac, Brazil).

\section{Antimicrobial Susceptibility Test}

Following the recommendations of the Clinical and Laboratory Standards Institute (CLSI, 2005), the antimicrobials used in the test were as follows: amikacin, tetracycline, cephalothin, cefotaxime, ceftazidime, aztreonam, cefoxitin, ceftriaxone and chloramphenicol (30 $\mu \mathrm{g} /$ disc) as well as sulphazotrin $(25 \mu \mathrm{g} /$ disc) and gentamycin and ampicillin (10 $\mu \mathrm{g} / \mathrm{disc})$. Strains of
Salmonella, grown on Case agar (Merck) for 24 hours at $37^{\circ} \mathrm{C}$, were inoculated in $4 \mathrm{ml}$ of sterile distilled water to achieve turbidity standard $\mathrm{n}^{0} 1$ of the McFarland scale, corresponding to $10^{8-9} \mathrm{CFU} / \mathrm{ml}$. A swab dipped in the solution was used to spread the inoculum across the surface of Muller Hinton agar, and disks containing the antibiotics (DME Polisensidisc ${ }^{\circledR}$ 4x6-Specialized Diagnostic Microbiology, São Paulo, Brazil) were applied to the plate. The resistance of the strains was assessed by measuring the inhibition of bacterial growth after incubation for $24 \mathrm{~h}$ at $37^{\circ} \mathrm{C}$. Escherichia coli ATCC 25922 was used for quality control testing.

\section{Statistical Analysis}

Fisher's exact test was performed to test the correlation between the frequencies of antimicrobial resistance in the bile and gallbladder epithelium. A $P$ value less than 0.05 was considered significant. The software used for statistical analysis was Biostat 2.0.

\section{Results and discussion}

In this analysis of 30 gallbladders, Salmonella spp. were identified by phenotypic characteristics in 23 samples. The microorganism was found more frequently in the gallbladder epithelium, with 18 samples testing positive. Salmonella was found in 16 bile samples, and in 11 samples, Salmonella was found in both the bile and the gallbladder epithelium (Table 1). The growth of this microorganism in the gallbladder is due to the development of several molecular mechanisms, including the presence of a lipopolysaccharide in the external membrane that acts as a barrier against bile, as described by Picken and Beachmam (1977), and the action of a limited number of genes, such as acrAB (Nikaido et al., 1998; Ma et al., 1994), phoP (Van Velkinburgh and Gunn, 1999), tolR (Prouty et al., 2002) and wec (Ramos-Morales et al., 2003). In antimicrobial susceptibility testing, strains of Salmonella

Table 1: Salmonella spp isolated from the liquid and epithelium of gallbladders from 30 cattle slaughtered

\begin{tabular}{lc}
\hline Gallbladders & \multicolumn{1}{c}{ Salmonela spp isolated of gallbladers } \\
\hline Bile $(n=16)$ & $2,3,4,5,8,10,11,13,15,16,17,21,25,27,28,30$ \\
Epithelium $(n=18)$ & $4,5,6,7,8,9,10,13,16,17,19,20,22,25,27,28,29,30$
\end{tabular}

from both bile and gallbladder epithelium showed resistance to the antimicrobials cephalothin, sulfazothrim and ampicillin (Table 2). The high frequency of resistance to cephalothin was expected because it is a first-generation cephalosporin with weaker activity against Gram-negative bacteria, as observed by Spinosa et al. (2002). According to Davis et al. (2007), the AmpC beta-lactamase gene (cmy-2) is responsible for encoding resistance to cephalosporin spectrum in Salmonella spp. Zhao et al. (2007), analyzed 129 cattle and found that $66 \%$ of Salmonella strains were resistant to ampicillin. Davis et al. (2007) reported that between 2001 and 2004, 79.6\% of Salmonella Dublin isolates from cattle were resistant to ampicillin and $32.7 \%$ to trimethoprimsulfa. 
Table 2: Percentage of Salmonella strains resistant to antimicrobials isolated from the liquid and epithelium of the cattle gallbladder slaughtered

\begin{tabular}{cccc}
\hline Antimicrobials & Bile $(\mathrm{n}=16)$ & Epithelium $(\mathrm{n}=18)$ & $P$ - value \\
\hline Amikacin & 37.50 & 33.33 & 1.00 \\
Ampicillin & 81.25 & 66.66 & 0.68 \\
Cephalothin & 93.75 & 94.44 & 1.00 \\
Cefotaxime & 62.50 & 16.66 & 0.01 \\
Ceftadizime & 37.50 & 16.66 & 0.68 \\
Sulfazothrim & 93.75 & 72.22 & 0.18 \\
Aztreonam & 25.00 & 16.66 & 0.68 \\
Cefoxitin & 68.75 & 61.11 & 0.72 \\
Ceftriaxone & 37.50 & 33.33 & 1.00 \\
Chloramphenicol & 50.00 & 33.33 & 0.48 \\
Gentamicin & 62.50 & 55.55 & 0.73 \\
Tetracycline & 68.75 & 50.00 & 0.31 \\
\hline
\end{tabular}

a Fisher's exact test

Although resistance to chloramphenicol was only present in about $50 \%$ of Salmonella strains present in the bile, Prouty et al. (2004a) reported that pre-exposure to bile at sublethal concentrations confers resistance to chloramphenicol by activating the bile-induced operon marAB.

In this study, $6.25 \%$ of the strains present in bile and $5.55 \%$ of those in the gallbladder epithelium were resistant to 12 antimicrobials (Figure 1). The indiscriminate use of antimicrobials in livestock directly contributes to the development of Salmonella MAR. This fact has alarming consequences for public health because it reduces the number of therapy options in cases of invasive infection in animals and humans (Zhao et al., 2007).

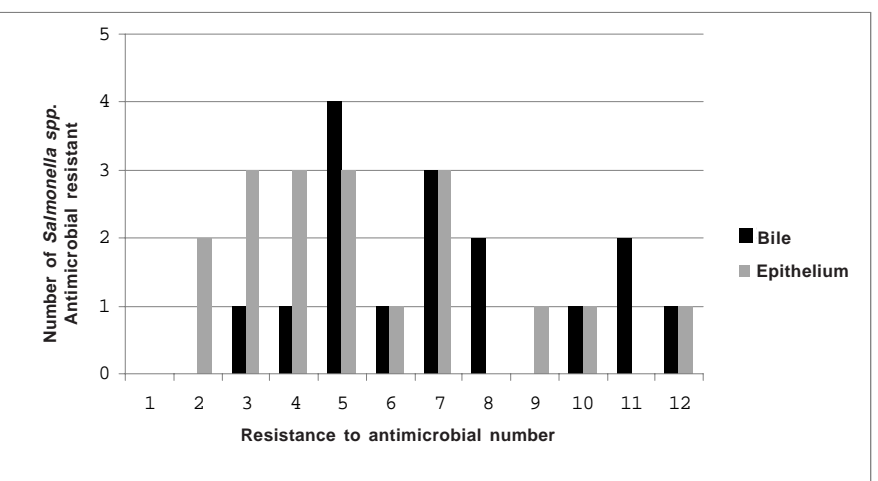

Figure 1: Resistance profile of Salmonella strains isolated from bile and gallbladder epithelium of cattle slaughtered

In gallbladder epithelium, the highest sensitivity (Table 2) occurred with the drugs cefotaxime, ceftadizime and aztreonam, and in bile, sensitivity was increased to aztreonam, which should therefore be considered the drug of choice for the control of Salmonella spp. in cattle. Our findings corroborate those of Chandra et al. (2005), who isolated species of Salmonella in the gallbladder and mesenteric lymph nodes of goats and also found aztreonam to be effective against most serovars.

In this study, the frequencies of resistance to each drug in bile and gallbladder epithelium (Table 3 ) were not significantly different by Fisher's exact test $(P<0.05)$. Therefore, resistance to certain drugs is similar in both environments, with the exception of cefotaxime, to which microorganisms in bile showed significantly higher resistance $(P=0.01)$. When comparing the frequency of multidrug resistance of strains from bile and epithelium of the same organ (Table 3), Fisher's exact test did not show any statistical difference, although the average drug resistance in bile was higher than the average found in gallbladder epithelium. In biliary fluid, bacteria can sometimes achieve greater resistance to a drug after being in direct contact with bile and, in the epithelium, bacteria may survive by aggregating to form a protective layer. According to Prouty et al. (2004a), the presence of bile salts in these bacteria induces the expression of genes that activate the efflux pump to expel the bile and, consequently, the antimicrobial agents.

Table 3: Resistance expressed by Salmonella strains isolated in the liquid and epithelium from the same gallbladder to number of antimicrobials tested*

\begin{tabular}{cccc}
\hline $\begin{array}{c}\text { Gallbladder with } \\
\text { Salmonella } \\
\text { isolated in bile and } \\
\text { epithelium }\end{array}$ & \multicolumn{3}{c}{$\begin{array}{c}\text { Resistance of Salmonella spp. to number } \\
\text { of antimicrobials }\end{array}$} \\
\cline { 2 - 4 } & Bile & Epithelium & $P$-value ${ }^{\mathrm{a}}$ \\
\hline 4 & 12 & 9 & 0.21 \\
5 & 7 & 10 & 0.37 \\
8 & 7 & 2 & 0.08 \\
10 & 5 & 2 & 0.37 \\
13 & 10 & 7 & 0.37 \\
16 & 6 & 7 & 1.00 \\
17 & 4 & 4 & 1.33 \\
25 & 5 & 5 & 1.31 \\
27 & 5 & 4 & 1.00 \\
28 & 5 & 6 & 1.00 \\
30 & 8 & 5 & 0.41 \\
Mean & 6.72 & 5.54 & $---{ }^{\mathrm{b}}$ \\
\hline
\end{tabular}

*12 antimicrobials tested

a Fisher's exact test.

b Value no calculed.

\section{Conclusion}

The ability of Salmonella spp. to survive the harsh environment of the gallbladder and become resistant to antimicrobials highlights the need for special care to be taken during the raising and slaughter of cattle in order to prevent contamination.

The use of drugs in livestock should be restricted. At slaughter, extreme caution is required to avoid the contamination of carcasses, parts of carcasses, organs and viscera, equipment surfaces, instrumental work and handlers' hands with bile and gallbladder epithelium. Because gallstones have considerable market value as research samples, it is common to open the gallbladder at the slaughterhouse. As a result, bile is frequently spilled, often on the liver. 
Restriction of antimicrobial use in livestock and greater care when handling the gallbladder would have a prophylactic effect on the dissemination of MAR strains of Salmonella. Without these measures, the horizontal transmission of strains

\section{References}

BEGLEY, M.; GAHAN, C.G.M.; HILL, C. The interaction between bacteria and bile. Microbiology Reviews, v. 29, p. 625-651, 2005.

CHANDRA, M.; SINGH, B.R.; SHANKAR, H.; AGARWAL, M.; AGRAWAL, R.K.; SHARMA, G.; BABU, N. Study on prevalence of Salmonella infection in goats. Small Ruminant Research, p.1-7, 2005. CLINICAL AND LABORATORY STANDARDS INSTITUTE (CLSI). Performance Standards for Antimicrobial Susceptibility Testing; Fifteenth Informational Supplement. Approved Standard, eight ed. M2-A8. National Committee for Clinical Laboratory Standards, Wayne (PA), USA. 2005. 58 p.

DAVIS, M.A.; HANCOCK, D. D.; BESSER,T.E; DANIELS, J.B.;BAKER, K. N. K.; CALL, D.R. Antimicrobial resistance in Salmonella enterica serovar Dublin isolates from beef and dairy sources. Veterinary Microbiology, v.119, p. 221-230, 2007.

DEFRANCESCO, K.A.; COBBOLD, R.N.; RICE, D.H.; BESSER, T.E.; HANCOCK, D.D. Antimicrobial resistance of commensal Escherichia coli from dairy cattle associated with recent multi-resistant salmonellosis outbreaks. Veterinary Microbiology, v. 98, p. 55-61, 2004.

DUTTA, U., P. K.; KUMAR, G.R.; R. K. TANDON, R.K. Typhoid carriers among patients with gallstones are at increased risk for carcinoma of the gallbladder. American Journal Gastroenterology, v. 95, p. 784$787,2000$.

GUNN, J.S. Mechanisms of bacterial resistance and response to bile. Microbes and Infection, v. 2, p. 907-913, 2000.

MA, D.; COOK, D.N.; HEARST, J.E.; NIKAIDO, H. Efflux pumps and drug resistance in gram-negative bacteria. Trends Microbiology, v. 2, p. 489-493, 1994.

NIKAIDO, H.; BASINA, M.; NGUYEN, V.Y.; ROSENBERG, E.Y. Multidrug efflux pump acrab of Salmonella typhimurium excretes only those b-lactam antibiotics containing lipophilic side chains. Journal of Bacteriology, v. 180, n.17, p. 4686-4692, 1998.

PICKEN, R.N.; BEACHAM, I.R. Bacteriophage-resistant mutants of Escherichia coliK12. Location of receptors within the lipopolysaccharide. Journal of General Microbiology, v. 102, p. 305-318, 1977.

PIGNATO, S.; MARINO, A.M.; EMANUELE, M.C.; IANNOTTA,V.; CARACAPPA,S.; GIAMMANCO, G. Evaluation of New Culture Media for Rapid Detection and Isolation of Salmonellae in Foods. Applied and Environmental Microbiology, v. 61, n. 5, p. 1996-1999, 1995. through the food chain will lead to serious consequences for public health by limiting the number of antibiotics that are effective against these microorganisms.

PRIETO, A.I.; RAMOS-MORALES, F.; CASADESU, J. Bile-Induced DNA Damage in Salmonella enterica. Genetics, v. 168, p. 1787-1794, 2004. PROUTY, A.M.; BRODSKY, I.E.; FALKOW, S.; GUNN, J.S. Bile-saltmediated induction of antimicrobial and bile resistance in Salmonella typhimurium. Microbiology, v. 150, p. 775-783, 2004a.

PROUTY, A.M.; BRODSKY, I.E.; MANOS, J.;BELAS, R.; FALKOW, S.; GUNN, J.S. Transcriptional regulation of Salmonella enterica serovar Typhimurium genes by bile. FEMS Immunology and Medical Microbiology, v. 41, p. 177-185, 2004b.

PROUTY, A.M., SCHWESINGER, W.H.; GUNN, J.S. Biofilm formation and interaction with the surfaces of gallstones by Salmonella spp. Infection and Immunity, v. 70, p. 2640-2649, 2002.

RAMOS-MORALES, F.; PRIETO, A.I.; BEUZÓN, C.R.; HOLDEN, D.W.; CASADESÚS, J. Role for Salmonella enterica Enterobacterial Common Antigen in Bile Resistance and Virulence. Journal of Bacteriology, v. 185, n. 17, p. 5328-5332, 2003.

SINDAN. Sindicato Nacional da Indústria de Produtos para a Saúde Animal. Mercado veterinário por classes terapêuticas e mercado veterinário por espécie animal. From: < http://www.sindan.org.br/ sd/sindan/index.html>. Accessed on October 20, 2010.

SPINOSA, H.S.; GÓRNIAK, S.L.; BERNARDI, M.M. Chapter 37: BetaLactam antibiotics: penicillins and cephalosporins. In: Applied Pharmacology for Veterinary Medicine. 3th ed. Rio de Janeiro: Guanabara Koogan, 2002, 752 p.

STEENACKERS, H.; HERMANS, K.; VANDERLEYDEN, J.; DE KEERSMAECKER, S.C.J. Salmonella biofilms: An overview on occurrence, structure, regulation and eradication. Food Research International, 2011. Doi: 10.1016/j.foodres.2011.01.038.

VAN VELKINBURGH, J.C.; GUNN, J.S. PhoP-phoQ regulated loci are required for enhanced bile resistance in Salmonella spp. Infection and Immunity, v. 67, p. 1614-1622, 1999.

WRAY, C.; DAVIES, R.H. Chapter 10: Salmonella infections in cattle. In: C.Wray, \& A. Wray (Eds.). Salmonella in domestic animals (p. 169-191), CABI Publishing, 2000.

ZHAO, S.; MCDERMOTT, P.F.; WHITE, D.G.; QAIYUMI, S.; FRIEDMAN, S.L.; ABBOTT, J.W.; GLENN, A.; AYERS, S.L.; POST, K.W.; FALES, W.H.; WILSON, R.B.; REGGIARDO, C.; WALKER, R.D. Characterization of multidrug resistant Salmonella recovered from diseased animals. Veterinary Microbiology, v. 123, p. 122-132, 2007. 